\title{
Effect of Plant Extract Preparations on Microbial Number and Species Composition of the Honey Bee Intestinal Microbiocenosis Throughout the Overwintering Period
}

\section{Varis Tuktarov ${ }^{*}$, Rashit Farkhutdinov², Fitrat Yumaguzhin $^{3}$, Farit Valitov ${ }^{1}$, Dmitri SCHELECHOV $^{1}$}

${ }^{1}$ Department of Beekeeping, Private Animal Science and Breeding, Federal State Budgetary Educational Institution of Higher Professional Education, Bashkir State Agrarian University, Ufa, Russian Federation; ${ }^{2}$ Department of Biochemistry and Biotechnology, Federal State Budgetary Educational Establishment of Higher Education, Bashkir State University, Ufa, Russian Federation; ${ }^{3}$ Department of Animal Physiology, Biochemistry and Feeding, Federal State Budgetary Educational Institution of Higher Professional Education, Bashkir State Agrarian University, Ufa, Russian Federation.

\begin{abstract}
The paper describes the results of applying feed products containing plant extracts. The trade names of the feed products are 'Fitoask' and 'Fitovar'. Fitovar is derived from the extracts from the thallus of Lichen islandicus, the leaf of Betulla pendula, Eucalupti viminalis, the acerose leaf of Picea abies or Abies sibirica, the bark of Pópulus trémula, Allium sativum, Chelidónium május, Artemisia vulgáris, Thýmus serpýllum, Melissa officinalis extracts. The 'Fitoask' feed base contains the extracts from the leaf of Betulla pendula, Eucalupti viminalis, the acerose leaf of Picea abies или Ábies sibirica, and Filipendula ulmariae, Veronica longifolia, Equiseti Arvensis, Melissa officinalis, Thýmus serpýllum, Chelidónium május extracts, Helichrýsum arenárium flower extract, Pópulus trémula bark extract. The study focused on dark forest bee colonies (Apis millifera millifera L.). The research found that the intestinal microbiocenosis of honey bees in the experimental apiaries differed in qualitative and quantitative composition. It consisted mainly of staphylococci, yeast, mould fungi and enterobacteria. Thus, the study showed that the plant extract preparations reduced the incidence of ascospherosis in honey bees and lowered food consumption over the winter. Plant extract supplements can be more effective than chemicals in the preventive and health-improving treatment of honey bees in protected areas.
\end{abstract}

Keywords $\mid$ Apis millifera millifera L, Intestinal microbiocenosis, Herbal preparations, Ascospherosis, Overwintering of honey bee colonies

\footnotetext{
Received | July 19, 2021; Accepted | November 14, 2021; Published | December 15, 2021

${ }^{*}$ Correspondence | Varis Tuktarov, ${ }^{1}$ Department of Beekeeping, Private Animal Science and Breeding, Federal State Budgetary Educational Institution of Higher Professional Education, Bashkir State Agrarian University, Ufa, Russian Federation; Email: tuktarov.v@rambler.ru

Citation | Tuktarov V, Farkhutdinov R, Yumaguzhin F, Valitov F, Schelechov D (2022). Effect of plant extract preparations on microbial number and species composition of the honey bee intestinal microbiocenosis throughout the overwintering period. Adv. Anim. Vet. Sci. 10(1): 203-211.

DOI | http://dx.doi.org/10.17582/journal.aavs/2022/10.1.203.211

ISSN (Online) | 2307-8316; ISSN (Print) | 2309-3331
}

Copyright (c) 2022 Tuktarov et al. This is an open access article distributed under the Creative Commons Attribution License, which permits unrestricted use, distribution, and reproduction in any medium, provided the original work is properly cited.

\section{INTRODUCTION}

$\mathrm{T}$ he intestinal microbiocenosis of honey bees is associated with Apis millifera millifera L (Crotti et al., 2013). The state of the bee colony depends on the gut microflora (Tejerina et al., 2020). The bee colony life periods depend on the climate type and flora. The annual cycle of a bee colony consists of two periods: The first is the honey flow period, when honey bees are mainly outside the hive and contact the environmental microflora. The second is the overwintering period when honey bees are inside the hive and contact the hive microflora and colony members (Daisley et al., 2020). During the overwintering period, the bee colony cannot defecate, which results in various infections (Kwong and Moran, 2016). The honey bee intestinal microbiocenosis is known 
to form during the summer honey flow; it influences the microflora composition of the bee colony during overwintering affecting the health of the bee colonies and their productivity during honey flow (Kwong and Moran, 2016). Successful overwintering of honey bees depends on many factors: cold hardiness of a bee breed, proper hive maintenance, amount and quality of food in the hive, overwintering conditions, honey bee health and adequate maintenance during overwintering (Kwong and Moran, 2016; Balzan et al., 2020). Preparations containing natural components can prevent various side effects since the products differ from chemicals in the mechanism of action. They stimulate the body's immune defence (Ilyasov and Farkhutdinov, 2016; Yumaguzhin et al., 2020).

Ascosphaerosis is an infectious disease of bee colonies caused by the parasitic fungus Ascosphaera apis, affecting bee larvae (Crotti et al., 2013; Tejerina et al., 2020). The fungal spores get into apiary bee colonies mainly with pollen and nectar (Daisley et al., 2020; Tejerina et al., 2020). Ascospherosis in the bee colony results in the dead larvae, producing no population succession among adult bees, dramatically reducing the total number of honey bees and the bee colony losses (Kwong and Moran, 2016).

There is a critical spread of ascospherosis in Russia and the Republic of Bashkortostan (Yumaguzhin et al., 2020). Strategies for preventing and controlling bee colony diseases imply using complex preventive measures, simultaneously treating several pathogens in the hive. Russia and other countries traditionally use antibiotics and other synthetic antimicrobial polymers to treat diseases (Ruffinengo et al., 2000; Yumaguzhin et al., 2020). Environmental stressors result in a weaker immune system and produce a higher incidence rate of ascospherosis and other infections. The increased incidence of ascospherosis is associated with higher moisture in the hive and inappropriate nutrition (Sandrock et al., 2014; Ventsova and Safonov, 2021). High application of ineffective drugs also enhances resistance to $A$. apis and increases the ascospherosis incidence rates (Sandrock et al., 2014). Using chemical preparations to prevent and treat honey bee colonies is not effective against various diseases. The chemicals pollute bee products, weaken the immune system and increase the spread of infections in the bee colony (ascospherosis, American and European foulbrood, viral diseases) (Pohorecka, 2004; Sandrock et al., 2014; Plettner et al., 2017).

The latest trend in beekeeping is reducing chemicals in the treatment of honey bee diseases and a gradual shift to herbal preparations (Pohorecka, 2004; Ilyasov and Farkhutdinov, 2016; Yumaguzhin et al., 2020). Herbal medicinal products are effective against pathogens of bee colonies and do not suppress their immune system. Beekeeping products do not contain chemical pollutants and are safe for people (Sandrock et al., 2014).

It is crucial to refuse synthetic drugs in the preventive and therapeutic treatment of honey bee colonies in specially protected areas, including Bashkirskiy Ural Biosphere Reserve. This biosphere reserve boasts of its biodiversity: the area abounds in small-leaved linden Tilia cordata Mill. and is home to the Burzyan population of the dark forest bee Apis millifera millifera L (Ilyasov et al., 2015; Khisamov et al., 2019; Sultanova et al., 2019). Therefore, studying the efficacy of plant extract preparations in treating mycotic diseases and other infections in bee colonies, strengthening the immune system and enhancing honey production is crucial for preserving the unique Burzyan bee Apis millifera millifera L.

\section{THE OBJECT OF THE STUDY}

The study was conducted in two apiaries. The first apiary was located in the Altyn Solok entomological reserve (Burzyansky district) of the mountain-forest zone of the Republic of Bashkortostan (RB, Russia) (Khisamov et al., 2019). The second apiary was on the territory of the forest-steppe zone (Ufimskiy District, Republic of Bashkortostan).

Honeybees of the Middle Russian breed Apis millifera millifera L. were the object of the study. All experimental variants involved bee colonies kept in twelve-frame hives and had the same feeding and maintenance conditions. The bee colonies were divided into groups of five colonies each. Groups of honey bee colonies were made up using the matched pair design; the study considered indicators such as the number of bees in the colony and the amount of sealed brood and feed. For overwintering, bee colonies were placed in the premises that met veterinary technical requirements.

The purpose of the study was to assess the effect of plant extract preparations on the microbial number and species composition of honey bee gut microbiocenosis. The study also aimed to evaluate the efficacy of the preparations against Ascosphaera apis and estimate the effect on survival of bee colonies after overwintering, the colony growth in spring, the amount of honey collected during the season after the treatment.

\section{MATERIALS AND METHODS}

\section{THE STUDIED PREPARATIONS}

Two herbal products were used: 'Fitoask' (manufactured by 'OOO Travy Bashkirii'[LLC Herbs of Bashkiia], company standard 26795008-005-2015) and 'Fitovar' (Federal state budgetary educational institution of higher education 
Bashkir State Agrarian University). Fitovar is derived from the extracts from the thallus of Lichen islandicus, the leaf of Betulla pendula, Eucalupti viminalis, the acerose leaf of Picea abies or Ábies sibirica, the bark of Pópulus trémula, Allium sativum, Chelidónium május, Artemísia vulgáris, Thýmus serpýllum, Melissa officinalis extracts. Fitoask contains the extracts from the leaf of Betulla pendula, Eucalupti viminalis, the acerose leaf of Picea abies and Ábies sibirica, and Filipendula ulmariae, Veronica longifolia, Equiseti Arvensis, Melissa officinalis, Thýmus serpýllum, Chelidónium május extracts, Helichrýsum arenárium flower extract, Pópulus trémula bark extract (Yumaguzhin et al., 2020).

\section{STUdY DESIGN}

The preparations were introduced in the spring after the cleansing flight to prevent bacterial and fungal infections and stimulate the growth of bee colonies. The medicated syrup was poured in feeders or frames with empty honeycombs. The frames with the syrup were then placed in the brood section of the hive. The syrup input standard was $50 \mathrm{ml}$ per frame densely occupied by honey bees.

The fungistatic activity of the products was studied in three groups of bee colonies with five hives per group. The experiment used groups of bee colonies by matching similar pairs in terms of the number of honey bees in the colony, the amount of sealed brood and food in the hive. The preparations were added to the sugar syrup in the following ratios: group 1, the control group, received 50\% sugar syrup; group 2, experimental group1, received 50\% sugar syrup mixed with Fitovar; group 3, experimental group 2, received 50\% sugar syrup mixed with Fitoask.

Microscopic examination identified the presence of the pathogen Ascosphaera apis. To this end, the outer surface of the affected bee larvae sample was scraped and assessed (Yumaguzhin et al., 2020).

Bee colonies were assessed in terms of the following indicators: Colony survival after overwintering, the colony growth rate in spring, honey production after the treatment.

The number of honey bees in the colony was found by counting the number of frames occupied by honey bees on both sides in the evening after the daytime flight. Unless the colony occupied all of the frames, it was grouped with another bee colony. The number of frames in the experimental honey bee hives was counted twice for a more accurate indicator record.

The experiment started with autumn feeding. For the experiment, fifteen bee colonies were divided into three groups of five colonies each. Each group had the same quantity of honey bees, sealed brood and food.

\section{STUdy Methods}

The study evaluated honey bee intestinal microbiocenosis in two experimental groups, with five bee colonies in each group. The qualitative and quantitative composition of the intestinal microflora of honey bees was based on the technique described by Serdyuchenko et al. (2018). Before bacteriological analysis, the insects were euthanized with chloroform, treated with $70 \%$ ethyl alcohol to eliminate microorganisms from the outer surfaces of bees, and then washed with sterile saline solution. Then the intestines were removed from the bee's abdomen. The intestines of five bees, randomly selected, were ground in a mortar with $2 \mathrm{ml}$ of sterile saline solution. The fore part of the bees was also ground in $2 \mathrm{ml}$ of saline solution. The obtained suspensions were diluted tenfold up to $10^{-6}$ incl. The obtained dilutions were inoculated into differential diagnosis media: Endo's agar, Olkenitsky's medium (three sugarcane agar with urea), Chromocult Coliform Agar (Merck, Germany). The samples were incubated at $37^{\circ} \mathrm{C}$ for 24 hours. Microorganisms were identified using biochemical plates differentiating enterobacteria (PBDE, Diagnostic systems, Nizhny Novgorod), indicator paper systems (IPS, Microgen, Nizhny Novgorod). The microbial type was identified based on the diagrams and tables presented in Bergey's manual of systematic bacteriology (Krieg and Holt, 1984).

\section{StaTisTiCAL ANALYsis}

Statistical data analysis involved calculating the arithmetic mean, standard error, and Student's t-test using MS Excel 2010 (Microsoft) software. Differences were significant at $\mathrm{p}<0.05$.

Table 1: Indicators of bee colonies at the beginning (12.05.2020) and the end of the experiment (14.08.2020), $\mathrm{n}=5$ (the average per 1 bee colony).

\begin{tabular}{|c|c|c|c|c|c|c|c|}
\hline \multirow[t]{2}{*}{$\begin{array}{l}\text { Group of bee } \\
\text { colonies }\end{array}$} & \multicolumn{2}{|c|}{$\begin{array}{l}\text { Number of hive frames } \\
\text { occupied by bees, pcs, } M \pm m\end{array}$} & \multicolumn{2}{|c|}{$\begin{array}{l}\text { Sealed brood, brood cells, } \\
\qquad \mathbf{M} \pm \mathbf{m}\end{array}$} & \multicolumn{2}{|c|}{ 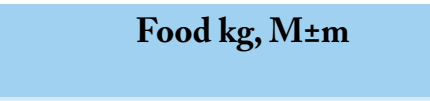 } & \multirow{2}{*}{$\begin{array}{l}\text { Commercial } \\
\text { honey, } \mathrm{kg}, \mathrm{M} \pm \mathrm{m} \\
\text { Experiment end }\end{array}$} \\
\hline & $\begin{array}{l}\text { Experiment } \\
\text { start }\end{array}$ & $\begin{array}{l}\text { Experiment } \\
\text { end }\end{array}$ & $\begin{array}{l}\text { Experiment } \\
\text { start }\end{array}$ & $\begin{array}{l}\text { Experiment } \\
\text { end }\end{array}$ & $\begin{array}{l}\text { Experiment } \\
\text { start }\end{array}$ & $\begin{array}{l}\text { Experiment } \\
\text { end }\end{array}$ & \\
\hline Control & $6.4 \pm 0.11$ & $9.6 \pm 0.13$ & $130.8 \pm 19.38$ & $91.2 \pm 42.7$ & $4.72 \pm 0.02$ & $26.86 \pm 0.7$ & \\
\hline Fitovar & $6.6 \pm 0.13$ & $10.8 \pm 0.3$ & $133.6 \pm 28.15$ & $127.8 \pm 67.8$ & $4.68 \pm 0.05$ & $28.56 \pm 0.5$ & $21 \pm 1.2$ \\
\hline Fitoask & $6.8 \pm 0.16$ & $10.2 \pm 0.3$ & $132.6 \pm 31.28$ & $123.6 \pm 20.3$ & $4.76 \pm 0.1$ & $27.9 \pm 1.2$ & $20 \pm 0.9$ \\
\hline
\end{tabular}

Statistically significant differences between the samples are shown in bold $(p<0.05)$. 


\section{RESULTS AND DISCUSSION}

The study recorded almost the same number of honey bees in all experimental colonies at the beginning (spring), with an average of 6.6 seams of bees (Table 1). The sealed brood values ranged131.8-132.8 brood cells, and food values were $4.68-4.72 \mathrm{~kg}$. The experimental groups were similar by the indicators specified in the Table 1 .

The first portion of the medicated syrup was introduced immediately after the beehive inspection, and the second portion was introduced three days later. In mid-August, the bee colonies state was assessed. Data on the number of honey bees in the colony, the sealed brood and commercial honey are provided in Table 1.

Table 1 shows that the control group occupied about 9.6 frames; 10.5 frames were occupied in the Fitovar group, and 10.6 frames in the Fitoask group. The sealed brood was 94.2 hundred cells in the control group, 127.8 hundred cells in the Fitovar group, 123.6 hundred cells in the Fitoask group. The commercial honey yield was the highest in the Fitovar group $(28.56 \mathrm{~kg})$, followed by the Fitoask group $(27.9 \mathrm{~kg})$, and the lowest honey yield (26.86 $\mathrm{kg}$ ) was recorded in the control group. By the end of the experiment, the inspection of bee colonies state revealed the best effect in the Fitovar group. The data indicate that the number of honey bees in the colony enhanced by $6.3-$ $12.5 \%$ due to fungicides, the sealed brood rose by $35.5-$ $40.1 \%$ and honey production improved by $2.4-6.3 \%$.

The inspection showed that both herbal preparations positively affected commercially valuable indicators by the end of the experiment. The preparations enhanced the sealed brood and honey production in the bee colonies and improved the flight activity of honey bees. Fitoask showed 4-5\% lower efficacy than Fitovar.

\section{BROOD AFFECTED BY ASCOSPHEROSIS}

Five years of observing the experimental apiaries in spring showed that the ascospherosis incidence in bee colonies was $50-70 \%$. Along with the analysis of productivity of bee colonies, the study investigated the effect of herbal preparations on the brood affected by ascospherosis. Figure 1 demonstrates that the differences in the number of affected larvae were initially insignificant; after ten days, the number decreased by $24 \%$ in the Fitovar group and $36 \%$ in the Fitoask group. In the control group, the number of affected larvae increased by $16 \%$, indicating the development of the disease in bee colonies without treatment (Figure 1). After 20 days, the number of affected larvae was lower than the initial values in the experimental groups. In the control group, the number of larvae affected rose by $32 \%$. After 30 days, single affected larvae were found in the experimental groups. In the control group, self-healing of bee colonies was observed: The number of affected larvae was $18 \%$ higher than the initial value.

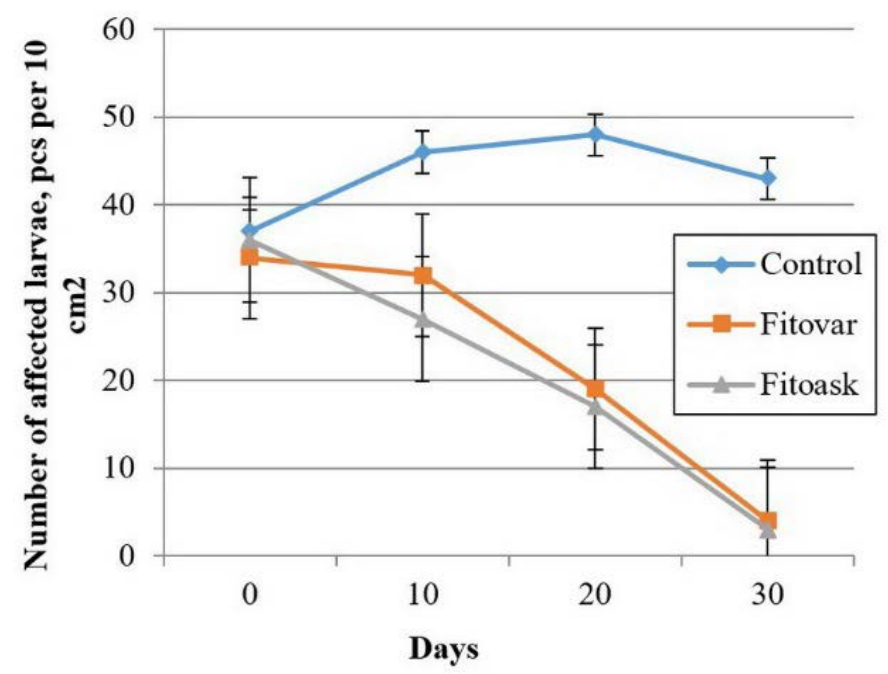

Figure 1: Fungistatic action of different herbal preparations on the course of ascospherosis in bee colonies (as of 12.05.2020), $\mathrm{n}=5$.

The experimental groups observed no visible signs of ascospherosis (the absence of dead larvae in the honeycomb frames and on the hive bottom boards) after about 1.5 months; in the control group, after 2.5-3 months.

\section{Microbial NUMber AND COMPOSITION OF HONEY \\ BEE GUT MICROFLORA}

The total microbial number changed in March compared to November. The Fitovar group had $227 \%$ higher values in the Ufimskiy apiary and 211\% higher in the Burzyansky apiary. In the Fitoask group, the figures increased by 249 and $252 \%$, respectively. In the Burzyansky apiary, honey bees had a significant rise in the gut microbial number. However, in November, the figure was 23\% lower in the Fitoask group and $14 \%$ lower in the Fitovar group than the corresponding figures of the Ufimskiy apiary. In March, the Fitoask group values approximated the Fitovar group values in each district (Table 2).

Table 2 shows a decrease in the total microbial number in the experimental groups due to the plant extract preparations compared to the control group. By March, the values fell by $87 \%$ in the Fitovar group and $91 \%$ in the Fitoask group (the Ufimskiy apiary). In the Burzyansky apiary, a decline of $41 \%$ and $46 \%$ was recorded in the corresponding groups.

The overwintering period resulted in the growth of enterobacteria. In the Fitovar group, enterobacteria values rose by $121 \%$ in the Ufimskiy apiary and $147 \%$ in the Burzyansky apiary. In November, none of the samples had lactobacilli, and mould fungi were not detected in the experimental groups. In the Fitovar group, staphylococci rose by $218 \%$ (the Ufimskiy apiary) and $250 \%$ by 
March (the Burzyanskiy apiary). In the Fitoask group, staphylococci increased by $409 \%$ and $366 \%$, respectively. During the overwintering period, the yeast grew by $188 \%$ (the Ufimskiy apiary) and 104\% (the Burzyanskiy apiary) in the Fitovar group. In the Fitoask group, yeast values were $133 \%$ and $137 \%$ higher. Enterobacteria, staphylococci and yeast were the most numerous microbial types in the experimental groups of the Ufimsky apiary. The Burzyanskiy apiary experimental groups also contained enterobacteria, staphylococci but less yeast.

The two apiaries demonstrated some variation in species composition of the honey bee gut microbiocenosis (Table 2). The microbial pool rose by the end of the overwintering period due to the increased microbial number and new microbial groups such as staphylococci and lactobacteria.

In the Ufimskiy apiary, the Fitovar and Fitoask groups demonstrated lower Escherichia coli values than the control group. In contrast, the control group showed an increase in the bacteria. Lactobacillus plantarum, unidentified in November, was traced in all groups in March. Staphylococcus epidermidis was not found in March, though the bacteria had been detected in November. The March samples revealed Staphylococcus saprophyticus; the bacteria had not been traced in the control group in November and February. The Ufimsky apiary revealed growth of Candida krusei per unit volume of the gut during the overwintering period: an increase of 50,128, and 191\% was established in the control group, Fitovar and Fitoask groups, respectively. Candida tropicalis also rose by 42,77 and $31 \%$, respectively, compared to the November records.

Changes in the species composition of the gut microflora recorded in the Burzyansky apiary were similar to those observed in the Ufimskiy apiary (Table 3).

\section{HoNEY BEE COLONY OVERWINTERING}

The study revealed that the experimental groups that had received the herbal preparations in autumn overwintered better than the control group (Table 4). The Fitovar group recorded the best overwintering indicators. It consumed $10.7 \%$ less honey for the overwintering period, had more survived bees (by 17.8\%), and had a smaller number of dead bees (by 25.0\%) than the control group. The most inadequate overwintering indicators were observed in the control group. The Fitoask group had intermediate overwintering indicators.

\section{ECONOMIC EFFECTIVENESS}

After the experimental stage, the study assessed the Fitovar and Fitoask products in economic effectiveness (Table 5).

Table 5 indicates that Fitoask and Fitovar experimental groups improved the commercial honey yield by 15.2-
$17.8 \%$ per bee colony on average. The feeding of bee colonies with food supplemented with Fitovar required the most considerable financial inputs. However, the Fitovar group demonstrated a higher profit. The Fitovar group had a profitability index of $56.0 \%$, which was $3.2 \%$ higher than that in the Fitoask experimental group (52.8\%).

The studied properties of the herbal preparations are of great interest to beekeepers. The preparations can effectively treat ascospherosis in bee colonies and enhance biological indicators improving honey production and making honey bees more cold-tolerant.

Crotti et al. (2013) and Kwong and Moran (2016) stated the significance of the relative constancy in the honey bee gut microbiocenosis. The present study has revealed the instability of the microbiocenosis during overwintering, which can weaken the collective immunity in a bee colony (Daisley et al., 2020). Probiotics (Mishukovskaya et al., 2020) and plant extract preparations (Ilyasov and Farkhutdinov, 2016; Yumaguzhin et al., 2020) can be effective in this case. Indicators of bee colony overwintering depend on the population of winter bees that emerge in the late summer. Strong bee colonies with many young bees survive the harsh winter conditions; in spring, the colonies develop rapidly before the honey flow (Ilyasov and Farkhutdinov, 2016; Saltykova et al., 2018). The present study has revealed some variation in the microbial number and species composition of honey bee intestinal microbiocenosis during the overwintering period between the apiaries. Table 3 shows that the total microbial number was higher in the Ufimskiy apiary than in the Burzyansky apiary. The Ufimskiy apiary honey bees revealed more microorganisms in each microbial group (enterobacteria, staphylococci, yeast, mould fungi). The experimental groups had fewer microorganisms than the control group. The microbial load of the honey bee gut rose in all groups throughout the overwintering period. In the control group, the total microbial number increased by $277 \%$ (the Ufimskiy apiary) and 203\% (the Burzyansky apiary). The control group received sugar syrup in autumn, but it mainly relied on the honey reserves in winter. Honey was more contaminated in the Ufimskiy apiary (foreststeppe zone) than in the Burzyansky apiary (mountainforest zone).

Autumn feeding of honey bees with plant extract products reduced the five studied types of gut microorganisms. It is assumed that the "core" gut microbiota mediate susceptibility to disease and eventually shape disease ecology and evolution (Lively et al., 2014; Anderson and Ricigliano, 2017). The honey bees have simple gut microbiota, easy to enrich and modify (Kwong and Moran, 2015). The gut microbiota of honey bees can affect the endocrine and immune systems, susceptibility to disease, 
OPEN OACCESS

Table 2: Quantitative composition of the intestinal microflora of bees during overwintering (2019-2020).

\begin{tabular}{|c|c|c|c|}
\hline \multirow[t]{2}{*}{ Microorganisms } & \multicolumn{3}{|c|}{$\begin{array}{l}\text { Number of microorganisms, Ig CFU } \\
/ \mathrm{ml}\end{array}$} \\
\hline & November & February & March \\
\hline \multicolumn{4}{|l|}{ Ufimsky district } \\
\hline \multicolumn{4}{|l|}{ Control } \\
\hline Total & $10.1 \pm 0.2$ & $26.7 \pm 0.4$ & $38.1 \pm 0.3^{*}$ \\
\hline Enterobacteria & $3.8 \pm 0.2$ & $6.1 \pm 0.3$ & $7.9 \pm 0.5^{*}$ \\
\hline Lactobacilli & 0 & $0.6 \pm 0.09$ & $2.9 \pm 0.5$ \\
\hline Staphylococci & $2.1 \pm 0.7$ & $5.8 \pm 0.3$ & $7.6 \pm 0.1^{*}$ \\
\hline Yeast & $3.8 \pm 0.4$ & $6.2 \pm 0.8$ & $7.2 \pm 0.5^{*}$ \\
\hline Mould fungi & $0.4 \pm 0.01$ & $1,6 \pm 0,09$ & $2.4 \pm 0.02 *$ \\
\hline \multicolumn{4}{|l|}{ Fitovar } \\
\hline Total & $6.2 \pm 0.4$ & $16.8 \pm 0.2$ & $20.3 \pm 0.7^{*}$ \\
\hline Enterobacteria & $2.8 \pm 0.5$ & $4.8 \pm 0.9$ & $6.2 \pm 0.3^{*}$ \\
\hline Lactobacilli & 0 & $0.7 \pm 0.09$ & $2.4 \pm 0.1$ \\
\hline Staphylococci & $1.6 \pm 0.05$ & $4.2 \pm 0.5$ & $5.1 \pm 0.1^{*}$ \\
\hline Yeast & $1.8 \pm 0.04$ & $4.0 \pm 0.1$ & $5.2 \pm 0.3^{*}$ \\
\hline Mould fungi & 0 & $1.1 \pm 0.01$ & $1.4 \pm 0.03$ \\
\hline \multicolumn{4}{|l|}{ Fitoask } \\
\hline Total & $5.7 \pm 0.2$ & $17.7 \pm 0.4$ & $19.9 \pm 0.3^{*}$ \\
\hline Enterobacteria & $2.8 \pm 0.2$ & $6.1 \pm 0.3$ & $5.9 \pm 0.5^{*}$ \\
\hline Lactobacilli & 0 & $0.6 \pm 0.09$ & $2.9 \pm 0.5$ \\
\hline Staphylococci & $1.1 \pm 0.07$ & $5.8 \pm 0.3$ & $5.6 \pm 0.1^{*}$ \\
\hline Yeast & $1.8 \pm 0.04$ & $5.2 \pm 0.8$ & $4.2 \pm 0.5^{*}$ \\
\hline Mould fungi & 0 & $0.6 \pm 0.09$ & $1.3 \pm 0.02$ \\
\hline \multicolumn{4}{|c|}{ Burzyansky district } \\
\hline \multicolumn{4}{|l|}{ Control } \\
\hline Total & $7.8 \pm 0.8$ & $21.7 \pm 0.4$ & $23.7 \pm 0.3^{*}$ \\
\hline Enterobacteria & $2.6 \pm 0.2$ & $5.1 \pm 0.3$ & $6.9 \pm 0.8^{*}$ \\
\hline Lactobacilli & 0 & $0.9 \pm 0.09$ & $2.1 \pm 0.5$ \\
\hline Staphylococci & $2.1 \pm 0.7$ & $4.8 \pm 0.3$ & $6.1 \pm 0.1^{*}$ \\
\hline Yeast & $2.9 \pm 0.2$ & $4.2 \pm 0.8$ & $6.5 \pm 0.5^{*}$ \\
\hline Mould fungi & $0.2 \pm 0.01$ & $1.1 \pm 0.09$ & $2.1 \pm 0.02^{*}$ \\
\hline \multicolumn{4}{|l|}{ Fitovar } \\
\hline Total & $5.4 \pm 0.3$ & $17.6 \pm 0.2$ & $16.8 \pm 0.8^{*}$ \\
\hline Enterobacteria & $2.1 \pm 0.7$ & $6.8 \pm 0.5$ & $5.2 \pm 0.3^{*}$ \\
\hline Lactobacilli & 0 & $0.6 \pm 0.09$ & $1.9 \pm 0.5$ \\
\hline Staphylococci & $1.2 \pm 0.3$ & $4.9 \pm 0.5$ & $4.2 \pm 0.1^{*}$ \\
\hline Yeast & $2.1 \pm 0.2$ & $5.2 \pm 0.1$ & $4.3 \pm 0.3^{*}$ \\
\hline Mould fungi & 0 & $0.7 \pm 0.04$ & $1.2 \pm 0.3$ \\
\hline \multicolumn{4}{|l|}{ Fitoask } \\
\hline Total & $4.6 \pm 0.2$ & $14.9 \pm 0.4$ & $16.2 \pm 0.3^{*}$ \\
\hline Enterobacteria & $2.1 \pm 0.1$ & $5.9 \pm 0.3$ & $4.9 \pm 0.1^{*}$ \\
\hline Lactobacilli & 0 & $0.6 \pm 0.09$ & $2.2 \pm 0.7$ \\
\hline Staphylococci & $0.9 \pm 0.01$ & $4.6 \pm 0.3$ & $4.2 \pm 0.3^{*}$ \\
\hline Yeast & $1.6 \pm 0.02$ & $4.0 \pm 0.6$ & $3.8 \pm 0.7^{*}$ \\
\hline Mould fungi & 0 & $0.4 \pm 0.04$ & $1.1 \pm 0.03$ \\
\hline
\end{tabular}

Advances in Animal and Veterinary Sciences

Table 3: Species composition of honey bee intestinal microorganisms during the overwintering period (20192020).

\section{Species of microorganisms}

\section{$\mathrm{Ig} \mathbf{C F U} / \mathrm{ml}$}

November February March

Ufimsky district

Control

\begin{tabular}{llll} 
Escherichia coli & $3.1 \pm 0.2$ & $3.5 \pm 0.1$ & $4.7 \pm 0.3$ \\
\hline Lactobacillus plantarum & 0 & $1.2 \pm 0.2$ & $5.2 \pm 0.5$ \\
Staphylococcus epidermidis & $4.7 \pm 0.3$ & $5.1 \pm 0.4$ & 0 \\
Staphylococcus saprophyticus & 0 & 0 & $5.7 \pm 0.6$ \\
Candida krusei & $3.4 \pm 0.2$ & $3.7 \pm 0.6$ & $4.2 \pm 0.4$ \\
Candida tropicalis & $2.8 \pm 0.5$ & $3.9 \pm 0.3$ & $4.0 \pm 0.4$
\end{tabular}

Fitovar

$\begin{array}{llll}\text { Escherichia coli } & 1.1 \pm 0.1 & 0.5 \pm 0.01 & 0.7 \pm 0.1 \\ \text { Lactobacillus plantarum } & 0 & 2.2 \pm 0.3 & 5.4 \pm 0.5 \\ \text { Staphylococcus epidermidis } & 3.7 \pm 0.3 & 2.1 \pm 0.4 & 0 \\ \text { Staphylococcus saprophyticus } & 0 & 2.1 \pm 0.4 & 3.7 \pm 0.8 \\ \text { Candida krusei } & 1.4 \pm 0.2 & 2.7 \pm 0.4 & 3.2 \pm 0.6 \\ \text { Candida tropicalis } & 1.8 \pm 0.2 & 2.9 \pm 0.3 & 3.2 \pm 0.2\end{array}$

Fitoask

\begin{tabular}{|c|c|c|c|}
\hline Escherichia coli & $0.7 \pm 0.5$ & $0.1 \pm 0.03$ & $0.6 \pm 0.04$ \\
\hline Lactobacillus plantarum & 0 & $2.8 \pm 0.5$ & $6.4 \pm 0.5$ \\
\hline Staphylococcus epidermidis & $3.1 \pm 0.2$ & $1.5 \pm 0.1$ & 0 \\
\hline Staphylococcus saprophyticus & 0 & $2.5 \pm 0.1$ & $3.9 \pm 0.2$ \\
\hline Candida krusei & $1.2 \pm 0.1$ & $2.9 \pm 0.3$ & $3.5 \pm 0.1$ \\
\hline Candida tropicalis & $1.6 \pm 0.2$ & $1.7 \pm 0.2$ & $2.1 \pm 0.6$ \\
\hline \multicolumn{4}{|l|}{ Burzyansky district } \\
\hline \multicolumn{4}{|l|}{ Control } \\
\hline Escherichia coli & $2.3 \pm 0.1$ & $3.5 \pm 0.1$ & $4.7 \pm 0.1$ \\
\hline Lactobacillus plantarum & 0 & $1.5 \pm 0.2$ & $6.2 \pm 0.6$ \\
\hline Staphylococcus epidermidis & $2.7 \pm 0.8$ & $2.1 \pm 0.4$ & 0 \\
\hline Staphylococcus saprophyticus & 0 & $1.7 \pm 0.2$ & $3.7 \pm 0.6$ \\
\hline Candida krusei & $2.4 \pm 0.05$ & $3.2 \pm 0.6$ & $5.1 \pm 0.8$ \\
\hline Candida tropicalis & $1.8 \pm 0.07$ & $4.9 \pm 0.3$ & $6.2 \pm 0.4$ \\
\hline \multicolumn{4}{|l|}{ Fitovar } \\
\hline Escherichia coli & $1.1 \pm 0.03$ & $0.5 \pm 0.03$ & $0,7 \pm 0,01$ \\
\hline Lactobacillus plantarum & 0 & $1.1 \pm 0.08$ & $5.2 \pm 0.5$ \\
\hline Staphylococcus epidermidis & $2.7 \pm 0.5$ & $2.1 \pm 0.4$ & $0.3 \pm 0.02$ \\
\hline Staphylococcus saprophyticus & 0 & $1.2 \pm 0.02$ & $2.7 \pm 0.2$ \\
\hline Candida krusei & $1.4 \pm 0.07$ & $2.7 \pm 0.4$ & $4.2 \pm 0.5$ \\
\hline Candida tropicalis & $1.2 \pm 0.03$ & $2.9 \pm 0.3$ & $4.0 \pm 0.4$ \\
\hline \multicolumn{4}{|l|}{ Fitoask } \\
\hline Escherichia coli & $0.7 \pm 0.05$ & $0.1 \pm 0.02$ & $0.6 \pm 0.06$ \\
\hline Lactobacillus plantarum & 0 & $1.5 \pm 0.2$ & $5.8 \pm 0.3$ \\
\hline Staphylococcus epidermidis & $2.1 \pm 0.02$ & $1.7 \pm 0.05$ & 0 \\
\hline Staphylococcus saprophyticus & 0 & $1.2 \pm 0.2$ & $1.8 \pm 0.1$ \\
\hline Candida krusei & $1.05 \pm 0.06$ & $2.9 \pm 0.3$ & $3.5 \pm 0.5$ \\
\hline Candida tropicalis & $1.06 \pm 0.02$ & $2.7 \pm 0.2$ & $4.1 \pm 0.1$ \\
\hline
\end{tabular}


Table 4: Fungicides and results of honey bee overwintering (on average per family), 25.04.2020.

\begin{tabular}{|c|c|c|c|c|}
\hline \multirow[t]{2}{*}{ Indicator } & \multirow[t]{2}{*}{ Statistical indicator } & \multicolumn{3}{|c|}{ Group of bee colonies (type of supplementary feeding) } \\
\hline & & $\begin{array}{l}\text { Control Sugar syrup } \\
\text { (SS) }\end{array}$ & $\begin{array}{l}\text { Experimental } 1 \\
\text { (SS+ Fitovar) }\end{array}$ & $\begin{array}{l}\text { Experimental } 2 \\
\text { (SS+Fitoask) }\end{array}$ \\
\hline \multirow{3}{*}{$\begin{array}{l}\text { Number of hive frames } \\
\text { occupied by bees, pcs }\end{array}$} & Lim & $4-6$ & $4-6$ & $4-6$ \\
\hline & $\mathrm{M} \pm \mathrm{m}$ & $4.5 \pm 0.12$ & $5.3 \pm 0.07$ & $4.9 \pm 0.12$ \\
\hline & $\%$ related to the control & 100 & 117.8 & 108.9 \\
\hline \multirow{3}{*}{$\begin{array}{l}\text { Honey consumption } \\
\text { per } 1 \text { hive, } \mathrm{kg}\end{array}$} & Lim & $1.30-1.58$ & $1.14-1.35$ & $1.21-1.39$ \\
\hline & $\mathrm{M} \pm \mathrm{m}$ & $1.40 \pm 0.03$ & $1.25 \pm 0.02$ & $1.29 \pm 0.03$ \\
\hline & $\%$ related to the control & 100 & 89.3 & 92.1 \\
\hline \multirow{3}{*}{$\begin{array}{l}\text { Number of dead bees } \\
\text { during overwintering, } \mathrm{kg}\end{array}$} & Lim & $0.03-0.18$ & $0.02-0.06$ & $0.03-0.13$ \\
\hline & $\mathrm{M} \pm \mathrm{m}$ & $0.08 \pm 0.01$ & $0.06 \pm 0.00$ & $0.07 \pm 0.01$ \\
\hline & $\%$ related to the control & 100 & 75.0 & 87.5 \\
\hline \multirow{3}{*}{$\begin{array}{l}\text { Beehive cleanliness, } \\
\text { scores }\end{array}$} & Lim & $0-1$ & $0-1$ & $0-1$ \\
\hline & $\mathrm{M}_{ \pm} \mathrm{m}$ & $0.2 \pm 0.03$ & $0.2 \pm 0.02$ & $0.2 \pm 0.04$ \\
\hline & $\%$ related to the control & 100 & 100 & 100 \\
\hline
\end{tabular}

Table 5: The economic effectiveness of the research results (on average per bee colony), 2020.

\begin{tabular}{llll} 
Indicators & \multicolumn{3}{c}{ Group } \\
\cline { 2 - 4 } & control & Fitovar & Fitoask \\
Commercial honey produced, $\mathrm{kg}$ & $23 \pm 1.3$ & $27.1 \pm 1.8$ & $26.5 \pm 1.9$ \\
\hline Price for 1 kg of honey, USD & 5.2 & 5.2 & 5.2 \\
\hline $\begin{array}{l}\text { Cost of the obtained products - } \\
\text { total, USD }\end{array}$ & 119.6 & 140.9 & 138.3 \\
\hline Total costs, USD & 91.3 & 92.6 & 92.3 \\
\hline Extra costs included & - & 1.3 & 1 \\
\hline Prime cost of 1 kg, USD & 3.97 & 3.42 & 3.48 \\
\hline Net profit, USD & 31.3 & 51.88 & 48.85 \\
\hline Profitability, \% & 34.3 & 56.0 & 52.8
\end{tabular}

growth and development, nutrition, and behaviour (Anderson and Ricigliano, 2017). Recent studies have revealed that the gut microbiota of honey bees contain a stable bacterial community of six major gut bacteria species. The community ecosystem is integrated with the honey bee's physiology (Anderson and Ricigliano, 2017; Kwong and Moran, 2015). The honey bee microbiome is sensitive to drug effects and environmental factors (Jeyaprakash et al., 2003; Rotti et al., 2013; Moran, 2015; Engel et al., 2016; Muñoz-Colmenero et al., 2020). The present study has shown that the preventive preparations primarily suppress the growth of yeast and mould fungi. The microorganisms were not traced in November and did not inhibit the central bacterial community of honey bees gut.

Escherichia coli, Staphylococcus epidermidis, Staphylococcus saprophyticus were dominant in the honey bee gut microbiocenosis during the overwintering period. Throughout the overwintering period, the composition of the intestinal microflora changed significantly in all groups. February and March saw a rise in Staphylococcus genus $S$. epidermidis, S. saprophyticus, yeast fungi and Candidafungus genus-C.tropicalis, C. krusei. The number of E. coli increased in the control group. The study recorded low titers of $E$. coli in the gut of honey bees two months after the treatment (November) in both apiaries. The number of bacteria did not rise anymore throughout overwintering. The decrease in the number can be accounted for by the components of the herbal preparations (Muñoz-Colmenero et al., 2020; Ruffinengo et al., 2000; Yumaguzhin et al., 2020). Still, the mechanism of the prolonged action remains to be explained.

Proper veterinary and technical maintenance is required for high-quality management of long overwintering of bee colonies. Cold hardiness in bee colonies is the primary economic indicator. It depends on honey bees' physiological state, breed signs, quality and quantity of honey and bee bread harvested, and an overwintering technique (Qin et al., 2019). Offering food containing plant-extract preparations as preventive medications reduced the incidence of ascospherosis in honey bees and lowered winter feed consumption.

\section{CONCLUSIONS AND RECOMMENDATIONS}

The study found that the intestinal microbiocenosis of honey bees during the overwintering period differed in qualitative and quantitative composition. The gut microbiocenosis consisted mainly of staphylococci, yeast, mould fungi and enterobacteria.

The Fitoask and Fitovar products offered in early spring 
reduced the incidence of ascospherosis in honey bees by $90 \%$ and lowered the winter feed consumption by $42 \%$. Spring feeding enhanced the sealed brood by $39 \%$, improved commercial honey yield by about $50 \%$, and profitability of honey production by about $20 \%$.

The experimental bee colonies treated with herbal preparations in autumn overwintered better than the colonies of the control group. The best overwintering indicators were recorded in the bee colonies of the Fitovar group. They consumed $10.7 \%$ less honey for the overwintering period, had more survived bees (by $17.8 \%$ ), and had a lower number of dead bees (by 25.0\%) than the control group. The bee colonies of the control group demonstrated the most inadequate indicators of overwintering. Bee colonies of the Fitoask group occupied an intermediate position.

The study established some variation in the quantitative and qualitative composition of the intestinal microbiota of honey bees during overwintering (from autumn to spring). The findings can help modify the microflora with probiotics (at slight deviations) or herbal preparations when the pathogen microflora emerges.

Preventive and systematic treatment of bee colonies with herbal preparations of various therapeutic effects can keep honey bee productivity and resistance of bee colonies to pathogenic diseases at a high level. However, few studies are devoted to developing and testing herbal preparations for beekeeping purposes, although herbal products are the basis for organic beekeeping.

\section{NOVELTY STATEMENT}

The authors have developed the compositions of herbal preparations. The results of the influence of phytopreparation extracts on the intestinal microbiocenosis of honeybees, the incidence of ascospherosis in honeybees and the wintering of bees are published for the first time.

\section{AUTHOR'S CONTRIBUTION}

Varis Tuktarov - author of the research organization, carried out the processing of the results, assessment of the species composition of Intestinal microbiocenosis, preparation of an article for publication. Rashit Farkhutdinov - author of herbal formulations, a study of intestinal microbiocenosis was carried out, preparation of an article for publication. Fitrat Yumaguzhin - research on apiaries in Burzyanskiy district. Farit Valitov - research in the apiaries of the Ufimskiy District. Dmitri Schelechov - research in the apiaries of the Ufimskiy District.
CONFLICT OF INTERESTS

The authors have declared no conflict of interest.

\section{REFERENCES}

-Anderson KE, Ricigliano VA (2017). Honey bee gut dysbiosis: A novel context of disease ecology. Curr. Opin. Insect. Sci., 22: 125-132. https://doi.org/10.1016/j.cois.2017.05.020

- Balzan S, Carraro L, Merlanti R, Lucatello L, Capolongo F, Fontana F, Novelli E, Larini I, Vitulo N, Cardazzo B (2020). Microbial metabarcoding highlights different bacterial and fungal populations in honey samples from local beekeepers and market in north-eastern Italy. Int. J. Food Microbiol., 334: 108806. https://doi.org/10.1016/j. ijfoodmicro.2020.108806

- Crotti E, Sansonno L, Prosdocimi EM, Vacchini V, Hamdi C, Cherif A, Gonella E, Marzorati M, Balloi A (2013). Microbial symbionts of honeybees: a promising tool to improve honeybee health. New Biotechnol., 30(6): 716-722. https://doi.org/10.1016/j.nbt.2013.05.004

-Daisley BA, Chmiel JA, Pitek AP, Thompson GJ, Reid G (2020). Missing microbes in bees: How systematic depletion of key symbionts erodes immunity. Trends Microbiol., 8(12): 1010-1021. https://doi.org/10.1016/j.tim.2020.06.006

- Engel P, Kwong WK, Mcfrederick Q Anderson KE Barribeau M, Chandler JA, Cornman RS, Link C, Engel P, Kwong WK (2016). The bee microbiome: impact on bee health and model for evolution and ecology of hostmicrobe interactions. MBio7(2): e02164-15. https://doi. org $/ 10.1128 / \mathrm{mBio} .02164-15$

-Ilyasov RA, Farkhutdinov RG (2016). Herbal Dietary supplement with antifungal effect for increasing the productivity of honey bee colonies. Chapter 2. In: Honeybees: Biology, behavior and benefits, Editor: Daniaele Dreesen. Nova Science Publishers, Inc., Hauppauge, New York, pp. 15-22.

-Ilyasov RA, Kosarev MN, Neal A, Yumaguzhin FG (2015). Burzyan wild-hive honeybee Am mellifera in South Ural. Bee World, 92(1): 7-11. https://doi.org/10.1080/0005 772X.2015.1047634

-Jeyaprakash A, Hoy MA, Allsopp MH (2003). Bacterial diversity in worker adults of Apis mellifera capensis and Apis mellifera scutellata (Insecta: Hymenoptera) assessed using 16S rRNA sequences. J. Invertebr. Pathol., 84(2): 96103. https://doi.org/10.1016/j.jip.2003.08.007

- Khisamov R, Yanbaev Y, Yumaguzhin F, Farkhutdinov R, Ishbulatov M, Onuchin M, Mustafin R, Rakhmatullin Z, Talipov E (2019). Nectariferous potential and cadastral evaluation of honey resources of the wildlife Altyin Solok Reserve created for the conservation and reproduction of the Burzian population of the Apis mellifera L. Bulg. J. Agric. Sci., 25(S2): 140-149.

- Krieg NR, Holt JG (1984). Bergey's manual of systematic bacteriology (No. BOOK). Yi Hsien Publishing Co, Taipei.

-Kwong WK, Moran NA (2015). Evolution of host specialization in gut microbes: The bee gut as a model. Gut. Microb., 6(3): 214-220. https://doi.org/10.1080/19490976.2015.1047129

- Kwong WK, Moran NA (2016). Gut microbial communities of social bees. Nature Rev. Microbiol., 14(6): 374-384. https:// doi.org/10.1038/nrmicro.2016.43

- Lively CM, de Roode JC, Duffy MA, Graham AL, Koskella B (2014). Interesting open questions in disease ecology 
and evolution. Am. Naturalist, 184(S1): 1-8. https://doi. org/10.1086/677032

-Mishukovskaya G, Giniyatullin M, Tuktarov V, Khabirov A, Khaziahmetov F, Naurazbaeva A (2020). Effect of probiotic feed additives on honeybee colonies overwintering. Am. J. Anim. Vet. Sci., 15(4): 284-290. https://doi.org/10.3844/ ajavsp.2020.284.290

- Moran NA (2015). Genomics of the honeybee microbiome. Curr. Opin. Insect. Sci., 10: 22-28. https://doi.org/10.1016/j. cois.2015.04.003

-Muñoz-Colmenero M, Baroja-Careaga I, Kovačić M, Filipi J, Puškadija Z, Kezić N, Estonba A, Büchler R, Zarraonaindia I (2020). Differences in honey bee bacterial diversity and composition in agricultural and pristine environments a field study. Apidologie, 51(6): 1018-1037. https://doi. org/10.1007/s13592-020-00779-w

- Plettner E, Eliash N, Singh NK, Pinnelli GR, Soroker V (2017). The chemical ecology of host-parasite interaction as a target of Varroa destructor control agents. Apidologie, 48(1): 7892. https://doi.org/10.1007/s13592-016-0452-8

- Pohorecka K (2004). Effect of standardized plant herb extracts on general condition of the honeybee (Apis mellifera L.). Bul. Vet. Inst. Pulawy, 48: 415-419.

- Qin M, Wang H, Liu Z, Wang Y, Zhang W, Xu B (2019). Changes in cold tolerance during the overwintering period in Apis mellifera ligustica. J. Apic. Res., 58(5): 702-709. https://doi.org/10.1080/00218839.2019.1634461

-Rotti E, Sansonno L, Prosdocimi EM, Vacchini V, Hamdi C, Cherif A, Gonella E, Marzorati M, Balloi A (2013). Microbial symbionts of honeybees: A promising tool to improve honeybee health. New Biotechnol., 30(6): 716-722. https://doi.org/10.1016/j.nbt.2013.05.004

- Ruffinengo S, Peña NI, Clemente G, Palacio MA, Escande A (2000). Suitability of culture media for the production of ascospores and maintenance of Ascosphaera apis. J. Apic. Res., 39(3-4): 143-148. https://doi.org/10.1080/00218839.
2000.11101034

- Saltykova ES, Gaifullina LR, Kaskinova MD, Gataullin AR, Matniyazov RT, Poskryakov AV, Nikolenko AG (2018). Effect of chitosan on development of Nosema apis Microsporidia in honey bees. Microbiology, 87(5): 738-743. https://doi.org/10.1134/S0026261718050144

-Sandrock C, Tanadini M, Tanadini LG, Fauser-Misslin A, Potts SG, Neumann P (2014). Impact of chronic neonicotinoid exposure on honeybee colony performance and queen supersedure. PLoS One, 9(8): e103592. https://doi. org/10.1371/journal.pone.0103592

-Serdyuchenko IV, Koshchaev AG, Guguchvili NN, Zholobova IS, Donnik IM, Smirnov AM, Usha BV (2018). Microbiocenosis of the intestinal tract of honey bees and its correction. Online J. Biol. Sci., 18(1): 74-83. https://doi. org/10.3844/ojbsci.2018.74.83

- Sultanova R, Gabitov II, Yanbaev YA, Yumaguzhin FG, Martynova MV, Chudov IV, Tuktarov VR (2019). Forest melliferous resources as a sustainable development factor of beekeeping. Israel J. Ecol. Evol., 65(3-4): 77-84. https://doi. org/10.1163/22244662-20191049

- Tejerina MR, Benítez-Ahrendts MR, Audisio MC (2020). Lactobacillus salivarius A3iob reduces the incidence of Varroa destructor and Nosema spp. in Commercial Apiaries Located in the Northwest of Argentina. Probiot. Antimicr. Proteins, 12(4): 1360-1369. https://doi.org/10.1007/ s12602-020-09638-7

-Ventsova I, Safonov V (2021). The role of oxidative stress during pregnancy on obstetric pathology development in highyielding dairy cows. Am. J. Anim. Vet. Sci., 16(1): 7-14. https://doi.org/10.3844/ajavsp.2021.7.14

-Yumaguzhin F,Farkhutdinov R, Giniyatullin M, Mishukovskaya G, Tuktarov V, Azikaev M (2020). Determination of the fungicidal properties of plants and herbal combinations against ascosphaera apis 1.J. Global Pharma. Technol., 12(1): 80-88. 